\title{
Generationsskiftet som kom av sig
}

Ett centralt drag i de senaste seklernas europeiska jordbruksutveckling är att jorden huvudsakligen har brukats av små enheter och i stor utsträckning ägts av brukarfamiljen. Självständiga jordbrukare har på egen hand kontrollerat hur tillgången till och makten över egendom har reproducerats. Mot den bakgrunden framstår det som angeläget att analysera på vilka sätt egendom ägts. ${ }^{128} \mathrm{Det}$ framhålls ofta att äganderätten under 1800-talet individualiserades, vilket innebar att den enskilde ägarens handlingsutrymme ökade. ${ }^{129}$ Exemplet med syskonen Rundqvist i Duvemåla, som inledde denna bok, kännetecknades dock inte enbart av att de bodde ihop utan också av att de ägde gården tillsammans. Samägande mellan syskon är förvisso inte det som definierar syskonjordbruk, men ägandeförhållanden spelar likväl en central roll för hur egendomen hanterats och hur gården drivits.

Utgångspunkten för detta kapitel är att många syskonjordbruk kännetecknades av ett delat ägande mellan arvingarna. Ett fokus på samägande som praktik och problem torde göra det möjligt att belysa centrala drag i 1900-talets ägandeförhållanden och dra vissa övergripande slutsatser om syskonjordbrukens utveckling. Mot den bakgrunden är avsikten med kapitlet att analysera dels de formella förutsättningarna för samägande av jord, dels samägandets omfattning och hur denna företeelse uppfattades i samtiden. Dessa två aspekter kan jämföras med den tudelning i formella och informella restriktioner som ekonomen Douglass C. North gjort för att analysera institutioner och institutionell förändring. ${ }^{130}$ Hur såg regelverket för samägande ut? Inträffade förändringar i 
lagstiftningen som understödde en utveckling mot att syskon oftare övertog gårdar tillsammans? Vilken omfattning hade samägandet av jordbruksfastigheter under 1900-talet? Sågs det gemensamma innehavet som ett problem och i så fall på vilka grunder?

Framställningen tangerar omfattande jordpolitiska debatter om äganderättens villkor och familjejordbruket som produktionsform. Avsikten är dock inte att ge en fullständig redogörelse för dessa debatter - en sådan hade krävt åtskilligt större utrymme än vad som är möjligt inom ramen för denna bok - utan snarare att tydliggöra vissa tendenser och hur de utvecklats över tid. Delstudien bygger i huvudsak på material som speglar den rättsliga och politiska utvecklingen, framför allt statliga utredningar och riksdagsmaterial.

\section{Generationsväxlingens två moment}

Som konstaterades i förra kapitlet är det rimligt att utgå från att syskonjordbruk i regel var ett resultat av en generationsväxling. Arvsprocessen kan sägas ha två moment: överföring av egendom mellan generationer samt inlösen mellan arvingarna. ${ }^{131}$ Eftersom ingen lever för evigt inträffar överföringen alltid förr eller senare, alternativet är att gården säljs utanför släkten och då blir det av naturliga skäl inget generationsskifte. ${ }^{132}$ I en del fall kan själva överföringen innebära att hela egendomen hamnar i händerna på en ensam arvinge - om det endast finns en arvtagare eller om gården $i$ sin helhet säljs till en utvald arvinge. Historiskt sett var dock regeln att överföringen innebar att egendomen splittrades på flera arvingar. I enstaka fall kunde en sådan splittring bli bestående, exempelvis anförs ofta att den komplicerade egendomsstrukturen i övre Dalarna har sin grund i att arvskiftets splittrande egendomsfördelning bevarades. ${ }^{133}$ Den gängse ordningen var dock att egendomen åter lades samman genom att en arvinge på ett eller annat sätt löste in de övriga. De två momenten i generationsväxlingen var således komplementära: överföring splittrade, inlösen sammanfogade.

Generationsväxlingens båda moment har genom historien varit strikt reglerade. Arvslagstiftningen styrde fördelningen av egendomen mellan arvingarna och angav tydliga principer för hur 
arvslotterna skulle fogas samman igen. Enligt 1734 års lag ärvde söner dubbelt så mycket som döttrar och hade dessutom rätt att ta ut sin andel före sina systrar. Om det inte fanns tillräckligt med fast egendom för att alla barn skulle få egna gårdar hade dessutom en bror, såsom ägare av en större lott i egendomen, rätt att lösa ut en syster. ${ }^{134}$ Arvslagstiftningen stipulerade således en delning enbart på pappret, i praktiken skulle en son överta gården och kompensera sina medarvingar. En sådan ordning berodde dock inte enbart på arvsbestämmelserna utan följde också av jorddelningslagstiftningen. Rätten att klyva brukningsenheter i mindre delar var begränsad och gårdar fick inte bli så små att de inte kunde försörja innehavaren. ${ }^{135}$ Generationsskiftet var också underkastat bestämmelserna om arvejord och bördsrätt, vars grundtanke var att ärvd jord skulle behållas inom släkten. Sådan jord fick inte testamenteras bort, och om någon sålde arvejord utanför släkten stipulerade bördsrätten att egendomen under vissa förutsättningar kunde lösas tillbaka av säljarens släktingar. ${ }^{136}$ Det var ett skydd mot att en arvinge sålde sin arvslott till någon utanför släkten istället för att låta sig inlösas, eftersom övriga arvingar då kunde lösa tillbaka jorden med hänvisning till bördsrätten.

Arvslagstiftning, jorddelningslagar och bestämmelser om arvejord och bördsrätt skapade tillsammans en egendomsordning byggd på tre principer: jorden skulle hållas inom släkten, inte splittras upp och i första hand övertas av söner. Det typiska utfallet i en generationsväxling var sålunda att jorden i det första momentet delades upp mellan arvingarna och i det andra inlöstes av en son. Studier av svensk arvspraxis under 1700 - och 1800 -talen visar tydligt att detta i praktiken var den normala följden. ${ }^{137}$ Under första hälften av 1800-talet började emellertid grundsatserna i denna egendomsordning ifrågasättas under påverkan från liberala tankegångar. Restriktionerna mot hemmansklyvning var föremål för en häftig debatt, vilket bör ses mot bakgrund av den kraftiga nyodling som tagit fart under 1700-talets lopp. Bestämmelserna mildrades 1827 då det blev tillåtet med klyvning "till vad hemmantal som helst" på villkor att innehavaren var "besutten", vilket ansågs föreligga om minst tre vuxna kunde leva av gårdens avkastning. ${ }^{138}$ 
När lika arvsrätt mellan söner och döttrar infördes 1845 efter en lång och stundtals mycket intensiv politisk debatt förändrades arvsrätten i grunden. ${ }^{139}$ Regeln att större andelsägare i en gård hade rätt att lösa ut dem som ägde mindre lotter, vilket i praktiken hade gett söner företräde till föräldrarnas jord, blev närmast betydelselös. Införandet av lika arvsrätt rubbade dock inte grundprincipen om mäns förtur till jord. Den bestod även efter 1845, i en nykomponerad lagparagraf gjordes den rentav explicit: "äro delarne lika; hafwe då broder, eller den, som ärfwer broders lott, rättighet att systers lott till sig lösa”. ${ }^{140}$ En bakgrund till bestämmelsen var, åtminstone enligt den officiella debatten, en rädsla för att döttrars större arvslotter skulle leda till en alltför långtgående hemmansklyvning. ${ }^{141}$ Denna farhåga tog sig snart starkare uttryck och på 1850-talet infördes tillfälliga inskränkningar i rätten att dela jord. ${ }^{142}$ Någon återgång till äldre principer var det emellertid inte fråga om och under senare delen av 1800-talet luckrades åtskilliga delar av jordlagstiftningen upp.

Restriktionerna för arvejord försvann i praktiken med 1857 års testamentesbestämmelser, som gjorde det tillåtet att testamentera bort arvejord. ${ }^{143}$ Några år senare avvecklades även bördsrätten. ${ }^{144}$ Samtidigt mjukades bestämmelserna om hemmansklyvning ånyo upp och 1881 släpptes jorddelningen i princip helt fri. ${ }^{145}$ Ett knappt decennium senare väcktes förslag om att slutligt upphäva regeln om söners rätt att lösa ut systrar. Att detta motiverades med att bestämmelsen var "i strid med den i lag antagna grundsatsen om lika arfsrätt" trots att den hade tillkommit samtidigt illustrerar tydligt hur synsättet hade förändrats under loppet av en dryg mansålder. ${ }^{146}$ Eftersom argumentet att stävja hemmansklyvning dessutom hade fallit ifrån beslutade riksdagen 1890 slutligt att ta bort söners företräde till jord. ${ }^{147}$ Därmed hade den äldre egendomsordningens principer om jordens bundenhet till släkten, jordsplittringens begränsning och mäns företräde till jord förändrats i grunden. ${ }^{148}$ Frågan är nu hur dessa förändringar påverkade generationsväxlingen i praktiken. 


\section{Sammanhållning, splittring eller samägande?}

Den lika arvsrätten medförde att splittringen av egendom mellan arvingarna ökade. Samtidigt försvann de tidigare reglerna för hur sammanförandet av arvslotterna skulle genomföras. Hur generationsväxlingens andra moment skulle lösas blev därmed något som varje familj fick lösa internt. Det är dock svårt att dra några säkra slutsatser om vilka effekter dessa förändringar i realiteten fick, eftersom konkreta undersökningar i stor utsträckning saknas. Baserat på det fåtal studier som gjorts vill jag ändå föra ett tentativt resonemang om tre möjliga scenarion. Det mest troliga är att de ökade frihetsgraderna inte fick några större följder på gårdsnivå och att enheter fortsatt hölls samman över generationerna. Det berodde dock inte på att den lika arvsrätten kringgicks, tvärtom tyder allt på att den nya lagstiftningen respekterades. ${ }^{149}$ Döttrar fick således lika mycket i arv som sina bröder, men det var fortsatt de senare som i slutändan löste in sina medarvingar och övertog gården. ${ }^{150}$ Det finns bara några enstaka studier som berör arvsförhållanden under det tidiga 1900-talet, men de pekar på att lagstiftningens förväntan om att frågan om arvslotternas samlande skulle lösas inom familjerna i huvudsak uppfylldes. Det konstaterade även den så kallade Lagberedningen, som under mellankrigstiden omarbetade ärvdabalkens bestämmelser. I ett av sina betänkanden redogjorde beredningen för hur inlösensreglerna successivt avvecklats och diskuterade om särskilda åtgärder behövdes för att "undvika arvfallen egendoms fördelning på alltför många händer". ${ }^{151}$ Något sådant behov ansågs emellertid inte föreligga; frågan löstes "i praktiken regelmässigt på den godvilliga överenskommelsens väg", vanligen genom att "en delägare efter avtal med de övriga övertoge dessas lotter mot vederlag". ${ }^{152}$

Mycket tyder således på att gårdar fortsatt hölls samman och att inlösen verkställdes på frivillig väg. Däremot innebar den lika arvsrätten att äktenskapet blev mer betydelsefullt för den son som stod i begrepp att ta över gården. Kostnaden för att lösa ut medarvingar ökade betydligt och män blev, som Maria Sjöberg understryker, mer beroende av den egendom som hustrun medförde i boet. ${ }^{153}$ En möjlig följd av de nya förutsättningarna var att den ekonomiska 
differentieringen inom bondeklassen ökade. Just en sådan utveckling framträder i Sofia Holmlunds studie av arvsöverlåtelser i den uppländska socknen Estuna. I slutet av 1800-talet hände det där att stora gårdar splittrades upp i småbruk som i flera fall såldes vidare av arvingarna. ${ }^{154}$ Även Ulla Rosén, som undersöker ägobyten i Kumla, finner att smålotter och mindre jordlägenheter ökade i antal under 1800 -talets slut. ${ }^{155}$ För att förklara denna utveckling pekar Holmlund på två viktiga skäl: uppkomsten av alternativa försörjningsmöjligheter utanför jordbrukssektorn och förändrade maktförhållanden inom familjen. Ett mindre jordbruk kunde nu kombineras med lönearbete - och även små gårdar gav ägaren rätt till den statusfyllda titeln hemmansägare. När behovet av att underordna sig sina föräldrar inte längre var lika starkt kunde arvingar, istället för att få en mindre ekonomisk ersättning för sin arvsandel, kräva delning av jorden, antingen för eget bruk eller för att sälja sin lott på öppna marknaden. ${ }^{156}$

Holmlund visar att den nya lagstiftningen - friheten att dela jord samt döttrars rätt att både ärva lika och behålla sin lott kunde medföra att både gårdar och familjer splittrades. Oviljan till uppoffring för "familjens bästa" var omdebatterad i samtiden och konservativa skribenter tolkade dylika tendenser som tecken på en upplösning av bondesamhällets grundläggande värden. ${ }^{157}$ Den förändrade lagstiftningen kunde emellertid också få rakt motsatt följd. För att en gård skulle splittras krävdes nämligen att minst en arvinge drev igenom en skarp uppdelning av jorden. Om arvingarna underlät att vidta några åtgärder kvarstod ägandet och förvaltningen på dödsboet och dess delägare. Rättsläget för ägande och förvaltning i sådana fall var länge påtagligt oklart, vilket bör tolkas som att ägandeformen inte hade någon större betydelse. ${ }^{158}$ När regelverket förtydligades under 1920- och 1930-talen, i samband med Lagberedningens revision av ärvdabalken, var ett grundläggande antagande att dödsbon utgjorde en temporär ägandeform i avvaktan på ett nära förestående arvskifte. ${ }^{159}$ Samtidigt tillstod Lagberedningen att dödsbon i vissa fall kunde bestå under en längre tid, särskilt inom den jordbrukande befolkningen. Ett exempel var när en viss delägare "anses böra övertaga en lantegendom, [men] 
till följd av underårighet ännu ej är i tillfälle därtill”. ${ }^{160}$ I samband med att beredningen diskuterade syskons arvsrätt konstaterades emellertid att egendom inom jordbrukarbefolkningen "stundom behålles oskiftad mellan syskonen". ${ }^{161}$ Det hade enligt Lagberedningens mening sin grund i en djupt grundad samhörighetskänsla mellan syskonen, vilka sades "känna det som en naturlig förpliktelse att vid behov understödja och hjälpa varandra". ${ }^{162}$ Formuleringen antyder att det främst var yngre syskon som tidigt mist en förälder beredningen hade $\mathrm{i}$ åtanke, men hur länge egendomsgemenskapen i sådana fall tänktes bestå är oklart.

Ett fortsatt ägande i dödsboets form var en möjlig samägandeform, men även när egendomen på pappret skiftats mellan delägarna och dödsboet därmed upplösts, kunde den behållas under gemensam förvaltning. Om ingen arvinge bröt ut sin lott för eget bruk eller inlöste de övriga, bestod samägandet. Det är iögonfallande att samma år som söners rätt att lösa ut sina systrar utrangerades ur lagboken, aktualiserade en riksdagsmotion frågan om rättsregler för sådan samägd egendom. Även om motionen inte rakt av tog sin utgångspunkt i den ändrade arvslagstiftningen är det belysande att motionären, andrakammarledamoten Carl Nyström, utgick från en situation där flera personer "genom arf eller gåfva eller på annat dylikt sätt [...] blifva gemensamma ägare till en fastighet”. 163 Nyström menade att erfarenheten visade att sådana ägandeförhållanden ofta resulterade i tvister och söndring och påtalade särskilt att egendomens skötsel kunde bli lidande. Medan förvaltning av exempelvis bolag och föreningar var reglerad saknades emellertid bestämmelser om den gemensamma förvaltningen av samägda fastigheter. Han yrkade på att frågan borde utredas och regleras i lag. ${ }^{164}$ Nyströms förslag vann så småningom bifall, och efter att saken utretts och breddats till att även omfatta lösegendom antogs 1904 den så kallade samägandelagen. Den fastslog att alla delägarna hade lika rätt och att förvaltningen över det samägda i sin helhet krävde samtliga delägares godkännande. ${ }^{165}$

Att lagstiftningsåtgärder alls blev en fråga indikerar att samägande mellan arvingar förekom, men hur vanligt det var är omöjligt att säga. Lagberedningens uppgift att syskon ibland behöll gårdar oskiftade 
är lika svårbedömd, särskilt som beredningen inte underbyggde sina resonemang med empiriska data. Det finns dock andra tecken på att samägande mellan arvingar blev mer utbrett i början av 1900-talet. I en studie av ägandeförhållandena i tre Västgötasocknar kunde jag visa att samägande ökade kraftigt efter sekelskiftet 1900. Vid andra världskrigets slut utgjorde de mer än en tredjedel av alla ägoenheter. Förändringen var emellertid inte enbart kvantitativ. Samägandet tenderade att bli mer utsträckt över tid och många dödsbon kunde bestå under flera decennier. ${ }^{166}$ En statlig utredning 1937 om jordbrukets skuldsättning fann ett likartat mönster. Baserat på uppgifter från en enkätundersökning till bland annat landets häradshövdingar konstaterade utredningen att det på flera håll i landet förekom att jordbruk drevs vidare som sterbhus, även om företeelsen inte någonstans sades vara vanlig. Tillvägagångssättet uppgavs särskilt förekomma då någon arvinge var omyndig - eller "då dödsbodelägarna äro syskon och alla äro ogifta". ${ }^{167}$

\section{Familj, individ och kön}

Förändringarna i egendomsordningen under 180o-talet fick sannolikt flera följder och olika förfaringssätt existerade parallellt. För att kunna dra mer säkra slutsatser behövs ytterligare undersökningar av hur egendomen hanterats i praktiken, men ett rimligt antagande är att generationsväxlingen på de flesta gårdar även fortsatt slutade med att en arvinge löste ut sina medarvingar. Det finns dock flera uppgifter som tyder på att inlösensprocessen i många fall avstannade genom att arvingar antingen splittrade gårdar i flera småbruk eller under en längre tid fortsatte äga egendomen tillsammans.

Bakom båda dessa fall anas en spänning mellan familj och individ, vilken dock kunde ge olika resultat. Holmlund menar att splittringen av gårdar kan ses som ett hävdande av individens intressen på familjens bekostnad, vilket frammanar ett konfliktperspektiv mellan arvingarna. En likartad motsättning skymtar i Carl Nyströms motion från 1890, med skillnaden att följden inte blev splittring utan ett fortsatt samägande. De individuella intressena kunde med andra ord ge olika utfall. Det är dock intressant att dessa spänningar 
tycks ha förstärkts vid samma tid som tvånget att lösa in försvann och generationsväxlingens andra moment i högre grad blev en fråga för familjerna att lösa på egen hand. Den ökade friheten bör således inte tolkas som att familjen som kollektiv aktör blev mer central. Det var i första hand den enskilde arvingen som såg sina valmöjligheter öka. Han eller hon kunde försöka köpa ut sina syskon, låta sig bli utköpt, bryta ut sin andel till en egen fastighet eller nöja sig med att behålla sin jordlott. Eftersom den gemensamma förvaltningen fordrade enighet mellan delägarna gav den dessutom i princip varje arvinge vetorätt.

Följden kan mycket väl - delvis beroende på den lokala jordmarknadens utveckling - ha blivit en skarpare spänning mellan individuella och mer kollektiva familjestrategier. Det bör emellertid understrykas att den centrala rättsliga förändringen hade att göra med kön. Fram till 1890 kunde söner med lagligt tvång lösa ut döttrar, men därefter kunde den kvinna som så önskade behålla sin ärvda bit jord. En möjlig tolkning är således att de ökade spänningarna inte främst rörde förhållandet mellan individ och kollektiv, utan mellan arvingar av olika kön. Om kvinnor i kraft av den förändrade lagstiftningen i ökad utsträckning behöll sin ärvda jord istället för att köpas ut kunde konsekvenserna bli just de beskrivna: splittring eller samägande.

Resonemanget ovan är av tentativ natur, men illustrerar hur förändringar i generationsskiftet kunde ge olika följdverkningar. I hur stor utsträckning behöll kvinnor sin jord? Speglar ett ökat samägande att generationsskiftet avstannade på grund av konflikter mellan arvingarna? För att komma vidare i diskussionen behöver de vidare ramarna för jordbruket belysas. De val som gjordes vid generationsväxlingar uppstod inte i ett vakuum och valmöjligheterna förändrades över tid. I takt med att den statliga regleringen av jordbruket blev allt starkare under 1900-talets första hälft kan handlingsalternativen kopplas till förändringar i den statliga jordbrukspolitiken. Det är därför på sin plats att skissera några av dess huvuddrag. 


\section{Från småbruk till normjordbruk}

Den uppluckrade jorddelningslagstiftningen var en viktig faktor bakom framväxten av småbrukar- och egnahemsrörelserna efter sekelskiftet $1900 .{ }^{168}$ Dessa uppstod i ett komplicerat samspel mellan en rad samtida skeenden. Det enskilt viktigaste var emigrationen, ett problem som växte till enorma proportioner och framträdde som en nationell ödesfråga under seklets första årtionde. ${ }^{169}$ En central orsak till utflyttningen ansågs ha varit dåliga villkor inom jordbruket, och den insikten satte ambitionerna för jordbrukspolitiken under 1900-talets första decennier. Inledningsvis var målet att få till stånd bättre villkor och boendeförhållanden för jordbrukets arbetare genom uppförandet av bostadsegnahem, enheter med begränsad areal som inte var avsedda att utgöra självständiga jordbruk. ${ }^{170} \mathrm{I}$ kombination med en annalkande brist på lantarbetare och rädsla för en uppskruvad urbanisering utvecklades emellertid målsättningen till att skapa småbruk, och för att stödja nybildning av sådana inrättades under seklets första decennium en statlig lånefond. Ursprungligen anslogs 10 miljoner kronor för en femårsperiod, men utlåningen tog snabbt fart och under 1920-talet förmedlades mellan 16 och 18 miljoner kronor årligen. ${ }^{171}$ Gränserna för vad som kunde klassas som ett småbruk var vaga i samtiden och senare forskning har främst arbetat med kriterier för areal och arbetsförhållanden. Med utgångspunkt i tiden runt sekelskiftet 1900 menar exempelvis Nils Edling att småbruk vanligen inte var större än omkring åtta hektar och att de helt sköttes av jordbrukarfamiljen. ${ }^{172}$

Småbrukarpolitiken var livlig under hela 1920-talet, men i början av 1930-talet tilltog problemen. Småbrukens höga belåning i kombination med svårigheter att finna avsättning för produkterna gjorde dem extra sårbara när trettiotalskrisen bröt ut. Situationen underlättades knappast av att möjligheterna till biinkomster samtidigt minskade. På kort tid förändrades bilden av småbruken. Många av dem ansågs inte vara bärkraftiga nog och när mekaniseringstakten i jordbruket ökade frampå 1940-talet blev de snabbt akterseglade av större gårdar. ${ }^{173}$ Att emigrationen i princip hade upphört och småbrukarna inte levde i det tillstånd av frihet och självägande som idealbilden gjort gällande bidrog till krisstämpeln. Folklivsforskaren 


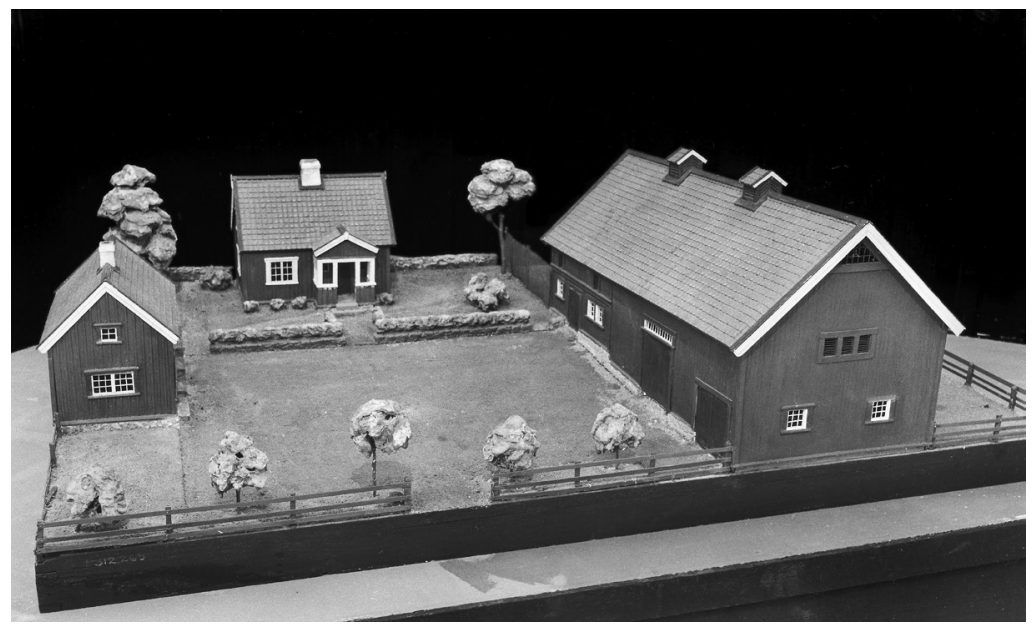

Småbrukets fördelar och möjligheter diskuterades livligt i början av 1900-talet. Modell av östgötskt småbruk, skapad för en utställning 1911 arrangerad av Nationalföreningen mot emigration. Foto: Peter Segemark/Nordiska museet.

och radiojournalisten Ludvig "Lubbe" Nordström, som kartlade det lortiga Sverige i en serie reportage i mitten av 1930-talet, skildrade talande nog småbruken under epitetet "paradiset som sprack". ${ }^{174}$

För att komma tillrätta med problemen tillsattes 1936 en statlig egnahemsutredning. I sitt betänkande konstaterade denna att nära två tredjedelar av alla egnahemslån hade gått till redan bebyggda enheter, vilket ur nybildningssynpunkt var ett stort misslyckande. ${ }^{175}$ Samtidigt fanns närmast en överproduktion av jordbruksprodukter för den svenska marknaden och den växande industrisektorn krävde mycket arbetskraft. Utredningen drog slutsatsen att det inte längre förelåg något behov av nya jordbruksenheter. Målet skulle istället vara att med tillskottsjord och sammanslagningar skapa fullvärdiga jordbruk som kunde försörja en familj. ${ }^{176} \mathrm{Med}$ stöd av uppgifter från bland annat landets kommunalnämnder ringade utredningen in enheter om åtminstone tio till femton hektar åker, samt på de flesta orter därtill ett par hektar skog, som framtidens ideal. ${ }^{177}$

Med omläggningen av småbruksverksamheten följde en omprövning av hela den statliga jordbrukspolitiken. Uppdraget att staka ut en framtida riktning lades på 1942 års jordbrukskommitté. I 
sitt huvudbetänkande 1946 satte de upp tre mål: inkomstmålet, produktionsmålet och effektivitetsmålet. Inkomstmålet fastslog att jordbrukarnas inkomster skulle följa utvecklingen för andra jämförbara grupper, särskilt industriarbetarna. Det skulle realiseras genom att staten bidrog till att hålla uppe priserna på jordbruksprodukter. Produktionsmålet, en direkt följd av erfarenheter under världskrigen, innebar att Sverige vid eventuellt krig eller avspärrning från världsmarknaden skulle vara självförsörjande på jordbruksprodukter. Till skillnad från de två övriga målen var effektivitetsmålet mer praktiskt utformat och fastslog att små jordbruk skulle läggas ner eller slås samman till mer bärkraftiga enheter. ${ }^{178}$

Effektivitetsmålet var en logisk fortsättning på den nyorientering av egnahemsverksamheten som skett vid 1930-talets slut. Ambitionerna ställdes dock högre. Förbättringen av jordbruket bestod i dels en inre rationalisering, varmed förstods tekniska förbättringar av olika slag, dels en yttre rationalisering, som gällde storlek och sammanslagningar av lämpliga brukningsdelar. Huvudmålet för den senare skulle enligt kommittén vara att skapa normjordbruk: bärkraftiga jordbruk med 20-30 hektar åker. Enheter med mindre areal ansågs vara förenade med en rad problem vad gällde driftsekonomin och effektivt nyttjande av arbetskraften. En total omläggning av jordbruksstrukturen till enheter över 20 hektar ansågs dock vara en på tok för ambitiös målsättning. År 1944 fanns det i Sverige 410 ooo brukningsenheter varav enbart 35 000, knappt nio procent, omfattade mer än 20 hektar. Målet inskränktes därför till att skapa lönsamhet på basjordbruk i storleksklassen 10-20 hektar, ett nog ambitiöst mål med tanke på att knappt en fjärdedel av alla brukningsenheter var större än 10 hektar $1944 .{ }^{179}$ Jordbrukets struktur satte följaktligen tydliga gränser och medförde även att rationaliseringstakten fick anpassas. Även om avsikten var att jordbruken skulle kunna försörja brukarfamiljen bedömde kommittén att det av sociala skäl var nödvändigt att under en relativt lång tid stödja även jordbruk på mindre än 10 hektar. ${ }^{180}$ Förslagen från Jordbrukskommittén bifölls i allt väsentligt av riksdagen genom antagandet av 1947 års jordbruksreform. ${ }^{181}$

För att förverkliga den nya jordbrukspolitiken krävdes effektiva 


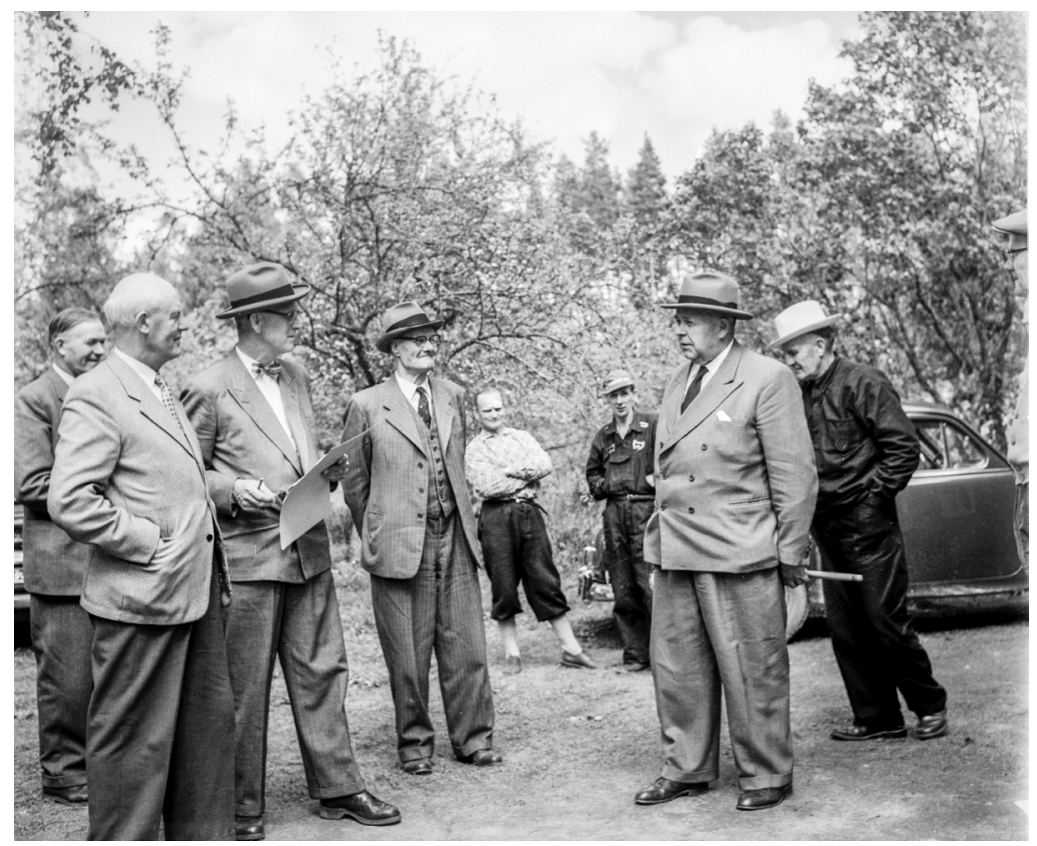

De regionala lantbruksnämnderna var sammansatta av lokala politiker och jordbrukare och erhöll snabbt en maktposition bland annat genom sin rätt att avgöra jordförvärvsärenden och bevilja medel för teknisk rationalisering. Lantbruksnämnden i Gävleborg på besök i Yxbo by i Hälsingland, maj 1956. Foto: P.W. Häger/ Länsmuseet i Gävleborg.

verktyg och ett sådant var jordförvärvslagen. Den hade sin grund i förhållandena på jordmarknaden. Förändringarna i egendomsordning under 1800-talet hade inneburit att jord i större utsträckning kunde köpas och säljas fritt. Handeln försiggick huvudsakligen inom böndernas led, men successivt började andra kapitalstarka aktörer ge sig in på marknaden och lägga under sig jord. Jordbrukarna själva påtalade tidigt problemen med denna utveckling och under första hälften av 1900-talet skärptes konflikten, särskilt i samband med världskrigen. Jordförvärvslagen trädde i kraft hösten 1945 för att förhindra att jord blev ett spekulationsobjekt. ${ }^{182}$ Lagen innebar att staten, genom nyinrättade lantbruksnämnder i varje län, skulle kontrollera enskilda jordtransaktioner och kunde sätta stopp för dem om köparen inte tillhörde den jordbrukande befolkningen. 
I den bakomliggande propositionen underströks samhällets behov att värna "ett starkt och bärkraftigt jordbruk som handhaves av en självägande och självständig jordbruksbefolkning". ${ }^{183}$ Genom jordförvärvslagen blev fastighetsmarknaden starkt reglerad, men lagen lämnade ett stort undantag: egendom som överfördes inom familjen behövde inget tillstånd. ${ }^{184}$ Uppfattningen om familjens rätt till bestämmande över egendom var således grundläggande och släktundantaget kom att utgöra en viktig del av jordförvärvslagstiftningen under hela 1900-talet. ${ }^{185}$ Men vilken familj var det som avsågs?

\section{Familj, jordbruk och familjejordbruk}

Det var Egnahemsutredningens slutbetänkande 1938 som på allvar etablerade begreppet "familjejordbruk" i den offentliga debatten. ${ }^{186}$ Utredningen arbetade fram en modell med tre storleksgrupper för egnahemsverksamheten: bostäder utan jordbruk, stödjordbruk där en eller flera familjemedlemmar fick sin huvudsakliga inkomst utanför jordbruket, samt familjejordbruk där jordbrukarfamiljen skulle "erhålla full sysselsättning och försörjning utan att behöva vara beroende av arbetstillfällen utom det egna jordbruket". ${ }^{187}$ Brukningsenheten skulle därtill inte vara så stor att den blev beroende av annan arbetskraft än familjemedlemmarnas. ${ }^{188}$ Familjejordbruket definierades därmed utifrån behov av och tillgång till arbetskraft. I betänkandena från 1942 års jordbrukskommitté var det ofrånkomligt att familjejordbruk berördes, trots att kommittén försökte distansera sig från småbrukspolitiken. Med sin inriktning på basjordbruk i storleksklassen 10-20 hektar kom deras förslag i praktiken att fullfölja tankegången om en satsning på bärkraftiga jordbruk byggda på familjemedlemmars arbetskraft. ${ }^{189}$

Familjejordbruket blev således en grundpelare i efterkrigstidens jordbrukspolitik. Jordbrukets status och beskaffenhet på dessa enheter diskuterades i detalj, men betydligt mindre uppmärksamhet ägnades åt begreppets förled. Vilka utgjorde egentligen familjen? Tystnaden bottnade i ett självklart och samfällt antagande: både Egnahemsutredningen och Jordbrukskommittén föreställde sig en 
kärnfamilj bestående av en manlig jordbrukare med hustru och minderåriga barn. ${ }^{190}$ Satsningen på familjejordbruk byggde på en tydlig familjeideologi och motiverades allmänt med att "innehavaren och hans familj" skulle garanteras full sysselsättning och försörjning. ${ }^{191}$ I ett försök att beräkna familjens arbetskapacitet utgick Egnahemsutredningen från arbetsförhållandena inom en "normalfamilj", en beteckning som avsåg "1,5 fullgod manlig och 1 fullgod kvinnlig arbetskraft eller sammanlagt 2-3 reducerade manskrafter (den kvinnliga uppskattad till o,8 manlig)". ${ }^{192}$ I ett av Jordbrukskommitténs betänkanden, där normjordbruk om minst 20 hektar anfördes som det ideala, framhölls dock ett vidare familjebegrepp som önskvärt: att"de egentliga bondejordbruken mera allmänt vore av sådan storlek, att de kunde bereda jämn sysselsättning åt två män”. ${ }^{193}$ Tanken var att det på sådana enheter skulle finnas två separata hushåll: jordbrukarfamiljen och en anställd arbetare som, om han kunde beredas egen bostad, även borde vara gift. En sådan lösning ansågs underlätta för bondehushållets familjebildning: "då sonen önskade bilda eget hem, skulle han kunna göra detta genom att övertaga den bostad de anställda tidigare innehaft". ${ }^{194}$

Iréne Flygare, som granskat genusrelationer i den svenska jordbruksdebatten, konstaterar att 1940-talets familjeideal bestod i flera decennier och understryker att familjen skildrades som ett tämligen oproblematiskt begrepp. Den antogs kort och gott bestå av en manlig jordbrukare, en hustru och några små barn. Jordbrukarfamiljen kom därmed enligt Flygare att framstå som statisk, helt fristående från släktingar och andra sociala nätverk. Den utvidgade familjen lyste med sin frånvaro; här nämndes inga bröder eller systrar, inga fastrar eller morbröder och - kanske mest överraskande - ingen äldre generation. ${ }^{195}$ Den moderna kärnfamiljen i familjejordbruket framträdde som i ett vakuum. Dels höll den sig för sig själv utan att söka arbete utanför hemmet, dels klarade den sig helst själv, utan att anlita annan arbetskraft. Vänder vi blicken bort från arbets- och brukarförhållanden för att istället granska familjerelationernas betydelse för äganderätten framträder emellertid ett helt annat familjeideal. Ett belysande exempel återfinns i Lagberedningens förslag till ny ärvdabalk 1925. I en bred historisk översikt konstaterades 
att släkten som social och ekonomisk institution till följd av samhällsutvecklingen tappat i betydelse, och att en allt starkare tonvikt nu lades på individen och "den trängre krets [...] som familjen utgör" ${ }^{196}$ Lagberedningen föreslog därför att arvsrätten inte längre borde utgå från blodsband utan från "känslan av en på skyldskap grundad ekonomisk och social samhörighet". 197

I denna samhörighet ingick förstås bröstarvingar, föräldrar och syskon, men Lagberedningen inkluderade dessutom syskonbarn och föräldrars syskon. Utvidgningen motiverades med den gängse "uppfattningen hos den jordbesittande befolkningen". ${ }^{198}$ Jordbrukarnas familjeideal fordrade med andra ord ett vidare familjebegrepp, och Lagberedningen poängterade den historiska bakgrunden och bondebefolkningens emotionella relation till släktens gårdar. ${ }^{199}$ Detta utvidgade familjeideal återspeglades även i jordförvärvslagstiftningen. Med relativt vidlyftiga undantag för släkttransaktioner - 1948 års jordförvärvslag lämnade undantag inte enbart för make och avkomlingar utan även för syskon och syskonbarn - skapades en ordning där jordägandet kopplades samman med en betydligt större släktgrupp än kärnfamiljen. ${ }^{200}$ Därmed lämnades en mycket stor andel av jordmarknaden utanför jordförvärvslagen. ${ }^{201}$ Målet att skydda böndernas jord från andra spekulanter uppnåddes således genom att jordägandet gjordes till en familjeangelägenhet inom en tämligen utvidgad familj, där alla slags egendomsrelationer mellan exempelvis syskon undantogs från prövning.

Kontrasten mellan de två familjeidealen är tydlig: ifråga om arbetskraft och jordbruksdrift står kärnfamiljen ensam och skildras närmast utan nära anförvanter, men när det kommer till ägandefrågor har de senare sin givna plats. Förklaringen till att dessa två synsätt förekom samtidigt kan sökas i den utveckling jordbruksfrågorna fick under 1900-talets första hälft. Det går en tydlig linje från 1940-talets jordbrukspolitik tillbaka till sekelskiftets småbrukaranda. Nils Edling, som ingående har granskat den politiska debatten om småbruken, framhäver att denna politik i vissa avseenden var en sorts familjepolitik eftersom den "bars upp av bestämda familjeideal". ${ }^{202}$ Han menar att decennierna runt sekelskiftet var en brytningstid, där uppfattningen om manligt och kvinnligt var 
under stark debatt. Satsningen på egnahemsbildning, med tydligare definierade roller för man och hustru, framställdes politiskt som ett sätt att främja ett borgerligt familjeideal och normalisera de omdebatterade förhållandena. ${ }^{203}$ Politiken utgick från "kärnfamiljens intimitet med pappa, mamma och barn avskilda i ett eget hus" och hade "den kunnige småbrukaren som tillsammans med hustru och barn drev ett litet, arbetsintensivt jordbruk" som mål. ${ }^{204}$ 1940-talets jordbrukspolitik övertog i stora drag detta perspektiv och ärvde även kärnfamiljsidealet. Att denna familj framstod som så isolerad från ett vidare släktsammanhang bör ses ur samma perspektiv. Småbrukarpolitiken syftade till nybildning av jordbruk; jordens historiska anknytning, släktskap och generationsväxlingar hade ingen naturlig plats i den strävan.

Motsättningen mellan de två familjeidealen framträder kanske allra tydligast i diskussionen om den så kallade förköpslagen. Bakgrunden till denna var att staten behövde ett kraftfullt verktyg för att verkställa strukturrationaliseringen, och förköpslagen innebar statlig förtur till jord som utbjöds på den öppna marknaden. I likhet med jordförvärvslagen hade även förköpslagen ett familjeundantag, men här kom de två synsätten på familjen i konflikt med varandra. Visserligen anmärkte 1942 års jordbrukskommitté att när enheter "i flera generationer ägts och brukats i samma släkt" kunde det vara rimligt med någon form av undantag för "barn eller eljest, till nära anhöriga". ${ }^{205}$ I slutändan höll dock utredningen fast vid sin snävare familjeuppfattning: enbart maka och barn föreslogs som undantag. Det erkändes att det fanns fall där transaktioner mellan syskon kunde vara rimliga - exempelvis om en äldre bror hade förvärvat föräldragården och senare ville överlåta den till en yngre bror - men att ge syskon en ovillkorad rätt att handla med varandra sågs som riskabelt; "detta skulle nämligen innebära, att man skulle avstänga rationaliseringsorganen från möjligheten att använda förköpsrätten i vissa fall, där inga berättigade hänsyn kunna åberopas för ett dylikt undantag, och där undantaget även skulle vara till men för rationaliseringsarbetet”. ${ }^{206}$ När förslaget sändes på remiss försvarades emellertid det vidare familjeidealet av ett flertal instanser som ville se en betydligt bredare undantagsrätt för 
transaktioner mellan familjemedlemmar. Regeringen valde slutligen en medelväg och utvidgade undantaget till att även gälla försäljning till syskon. ${ }^{207}$ Som kommer att framgå längre fram i kapitlet var Jordbrukskommitténs oro för egendomsförhållandenas effekt på rationaliseringsarbetet inte helt obefogad.

Både jordförvärvslagen och förköpslagen slöt således upp bakom tanken att jord skulle ägas och överföras inom familjen. Medan lagstiftningen gav stora möjligheter för staten att påverka hur jord fördelades mellan olika grupper, innehöll regelverket inga verktyg för att påverka egendomsfördelningen inom familjer. Trots målet att slå ihop brukningsenheter och rationalisera jordbruksstrukturen diskuterades inga förbud mot att dela upp jord vid generationsväxlingar och det framfördes över huvud taget inga synpunkter om risker för splittrat ägande eller samägande. Kungstanken var fortsatt att generationsväxlingen inom familjen skulle verkställas på frivillighetens väg. Inlösen mellan syskon var en naturlig del i generationsväxlingen och borde få fortgå. Förändringarna i jordbrukspolitiken bör emellertid också ha påverkat vilka handlingsalternativ som var möjliga vid generationsväxlingen. Att splittra gårdar för att därigenom skapa flera småbruk - antingen för eget bruk eller för att sälja vidare kunde möjligen utgöra ett alternativ när småbrukspolitiken stod på sin topp. När politiken växlade spår och statsstöden för mindre jordbruk upphörde torde det ha tett sig orealistiskt.

Till den politiska förändringen kom de effekter som övergången till ett mer animaliebaserat jordbruk fick. Enligt Ulrich Lange fick den avgörande följder för jordbrukets viktigaste ekonomibyggnad - ladugården. Mjölkproduktionens ökade betydelse krävde mer utrymme och decennierna runt sekelskiftet 1900 började även byggnadssättet förändras, från ett traditionellt och småskaligt byggande i timmer till större ladugårdar i stolpverk, gråsten och tegel. ${ }^{208}$ Det blev högkonjunktur för ett modernt ladugårdsbyggande. Utifrån en analys av beståndet i tjugo socknar 1939 visar Lange att ladugårdarna i huvudsak var byggda efter sekelskiftet och alltså förhållandevis nya. ${ }^{209}$ Själva byggnaderna blev ekonomiskt viktigare och mer värdefulla, en utveckling som fortsatte under de efterföljande decennierna. Byggnadernas ökande investeringskostnader 
gjorde det inte bara orimligt att splittra fungerande enheter i småbruk, även regelrätta hemmansklyvningar måste ekonomiskt ha framstått som ett allt mer orealistiskt alternativ. Det bör därför ha funnits en ökad strävan att hålla samman gårdarna. Vad innebar det i praktiken? Fullföljdes generationsväxlingen så att en arvinge övertog gården eller blev samägande mellan syskon vanligare?

Den nya jordbrukspolitiken rivstartade vid 1940-talets slut och under det följande decenniet gick omvandlingen fort. För att kunna ha översikt över denna utveckling uppstod tidigt ett behov av en genomgripande jordbruksstatistik. Statistiska centralbyråns jordbruksräkningar, som normalt genomfördes vart femte år från 1927, gav vissa grundläggande data, men de följdes snart av specialstudier som belyste olika skeden i jordbruksutvecklingen. ${ }^{210}$ Denna jordbruksstatistik gav uppgifter om arealer, brukningsföretag, arbetskraft, djurbesättningar, teknik och skördeutfall, men innehöll märkligt nog mycket knapphändig information om ägandeförhållanden. I 1944 års jordbruksräkning analyserades ägandet enbart utifrån ägarkategorierna staten, andra samfälligheter, aktiebolag och enskilda ägare. Någon vidare uppdelning av det enskilda ägandet, som var den helt dominerande kategorin, gjordes inte. ${ }^{211}$ Före 1950 är det därför svårt att utifrån offentliga uppgifter och statistik bryta ner ägandeförhållandena på ett sätt som gör det möjligt att analysera samägandets praktik över tid. I nästa kapitel gör jag ett försök att belysa ägandeförhållandena utifrån andra källmaterial, men först ska utvecklingen efter 1950 granskas. Fyra delperioder utkristalliserar sig, grovt sett en per decennium.

\section{Femtiotal: samägande identifieras som problem}

De rudimentära ägaruppgifterna i den officiella statistiken var en anledning till att Jordbrukets utredningsinstitut, som formellt sorterade under Sveriges lantbruksförbund (senare LRF), under 1950-talet genomförde en mer ingående jordbruksstudie där ett urval om 9000 brukningsenheter följdes under en tioårsperiod. ${ }^{212}$ Undersökningen visade i ett flertal rapporter att såväl antalet jordbruk som den totala åkerarealen minskade kraftigt under 
1950-talet. ${ }^{213}$ Totalt lades under decenniet nästan vart femte jordbruk i Sverige ned - i genomsnitt fjorton om dagen. ${ }^{214}$ Nedläggningen drabbade emellertid inte alla ägarkategorier: jordbruk som ägdes av sterbhus eller av flera ägare gemensamt hade tvärtom blivit fler. Sinsemellan var de två kategorierna till förväxling lika; det hade rentav "vid bearbetningen varit svårt att skilja på dessa båda ägareformer". ${ }^{215}$ Grunden till detta var att de båda ägarkategorierna hade samma ursprung: flerägda enheter sades vanligen uppkomma "genom att ett sterbhus skiftas och flera av delägarna - i många fall ogifta syskon - enas om fortsatt samägande". ${ }^{216}$

Uppgifter om att dödsboägandet ökat i omfattning framfördes under 1950-talet även i andra sammanhang. I 1954 års förslag till ny ärvdabalk sades det "i viss utsträckning" förekomma att ett dödsbo lämnades "oskiftat under avsevärd tid", en utveckling som ansågs "väcka betänkligheter" ${ }^{217}$ Det var dock först med rapporterna från Jordbrukets utredningsinstitut som omfattningen framgick. Sammanlagt tillhörde 1961 inte mindre än tolv procent av den svenska åkerarealen flerägda brukningsenheter och dödsbon. ${ }^{218}$ Många dödsbon hade bestått i åtskilliga år och samägande tycks dessutom ha varit vanligare på större enheter. Bara mellan 1951 och 1956 ökade andelen sterbhus med 5 procent på enheter om 10-20 hektar och mer än 20 procent på enheter om över 20 hektar. ${ }^{219}$

Samägandet ökade således, men vad berodde det på? I rapporterna från Jordbrukets utredningsinstitut märks en glidning i synen på problemet. Inledningsvis tolkades utvecklingen ur ett ekonomiskt perspektiv och det förutsattes att de flesta arvingarna hade lämnat landsbygden men behållit sin arvslott i gården. Det illustrerades med ett scenario där en son övertagit driften och hans syskon lämnat jordbruket och hembygden. En sådan utveckling kunde lätt låsa egendomsförhållandena; för den kvarvarande sonen var det svårt att ackumulera kapital för att kunna lösa ut syskonen, vilka i sin tur såg gården som en möjlighet till god avkastning för att i framtiden kunna sälja sin andel till ett bra pris och omvandla sin innestående fordran till kapital. ${ }^{220}$ I förlängningen kunde traditionella värden vara hotade och den "hävdvunna successionen far-son inom jordbruket äventyras". 221 


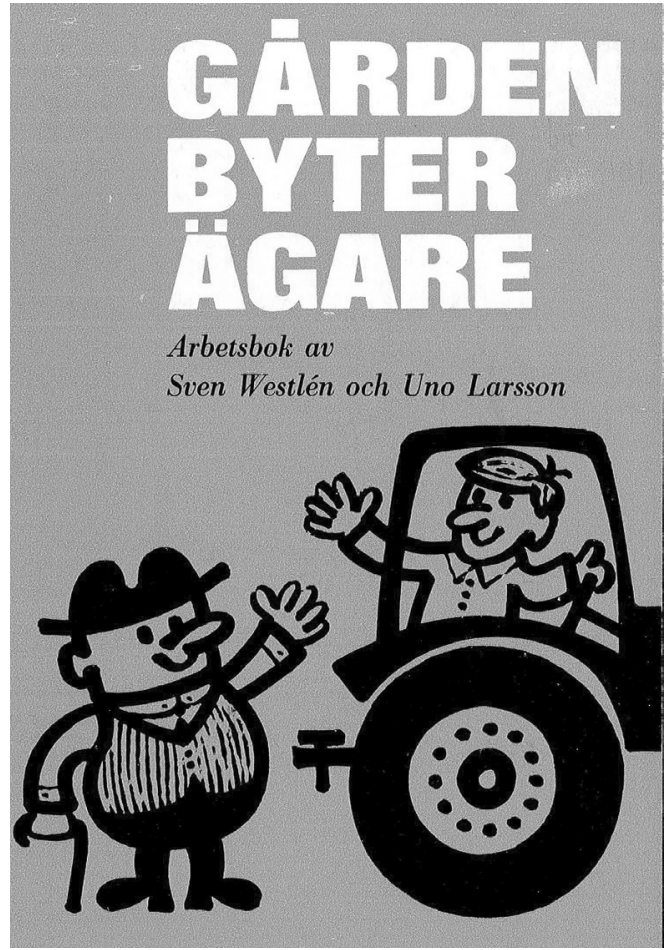

Den dominerande bilden, i såväl praktik som ideal, var att gården normalt överfördes från far till son. Framsidan till kursmaterialet från lantbrukarnas korrespondensskola LTK skildrade 1965 generationsväxlingen som en manlig angelägenhet. Den äldre mannen vinkar av den yngre, traktorn illustrerar framtiden.

I det ökade samägandet anades således en underliggande konflikt mellan arvingar med motsatta mål. Denna konflikt fogades in i den för samtiden aktuella motsättningen mellan land och stad: utvecklingen riskerade medföra att en allt större del av jorden genom arv överfördes till "den icke-jordbrukande delen av befolkningen", till men för den egentliga jordbruksbefolkningen. ${ }^{22}$ I grunden framträder här en ny syn på familjens överhöghet och förmåga att lösa generationsskiftet. Den tidigare linjen kan sägas ha varit att skydda familjen från otillbörlig konkurrens på jordmarknaden och utgå från att arvskiftet löstes mellan arvingarna utan statens inblandning. I utredningarna från Jordbrukets utredningsinstitut bryter ett nytt 
synsätt in. När arvingar i allt högre grad lämnade landsbygden och därmed inte längre räknades till den jordbrukande befolkningen sågs arvsfrågans lösning och jordägandets uppdelning inom familjen inte längre som en intern angelägenhet. Konflikten flyttade in i familjen och ställde saken på sin spets: var det rimligt att skydda jordbrukarna genom att hindra spekulanter utanför lantbrukets krets från att köpa jord, när samtidigt "åker och skogsmark via arvsfallen och sterbhusen överföres i andra gruppers händer"? 223

I senare rapporter framträder emellertid en annorlunda bild. I en mer djupgående granskning av de 9 ooo gårdarna, där bland annat innehavare av sterbhus intervjuades, visade sig majoriteten av delägarna ännu bo kvar på fastigheten och mindre än var femte önskade över huvud taget att fastigheten skulle skiftas. Delägarna, oftast mellan tre och fem personer, var syskon samt i en del fall en förälder. Könsfördelningen var helt jämn, vilket till viss del berodde på att änkor var betydligt vanligare än änklingar. Många av delägarna var ogifta, vilket inte berodde på att de var särskilt unga - medianåldern var närmare 45 år. ${ }^{224}$ På den direkta frågan varför boet inte hade skiftats var det enbart ett fåtal som förde fram ekonomiska förklaringar. Visserligen påpekades i en rapport att det kunde finnas anledning för arvingarna att inte öppet skylta med eventuell missämja, men det är påfallande att konflikter mellan de samägande arvingarna lyste med sin frånvaro i materialet. Bara i något enstaka fall angavs oenighet, svårigheter att lösa ut varandra eller kapitalplacering som förklaring till att egendomen inte skiftats. Det vanligaste var tvärtom att det fanns en god sammanhållning mellan delägarna samt en gemensam önskan att behålla gården i släkten. ${ }^{225}$

Rapporterna från Jordbrukets utredningsinstitut antyder att många generationsväxlingar under 1950-talet inte hade fullföljts med en inlösen mellan arvingarna. I försöken att förklara detta framträder olika perspektiv, präglade av såväl samhörighet som konflikt. Bakom den ökande andelen samägda jordbruksfastigheter finns troligen en rad olika situationer och familjeförhållanden, men det var de ogifta syskonen som lyftes fram i rapporterna. De passade inte in i den gängse familjemodellen, där jordbrukarfamiljen antogs bestå av en manlig brukare, en hustru och hemmavarande barn. I vissa av de 
intervjufrågor som Jordbrukets utredningsinstitut ställde om sterbhus förutsattes exempelvis någon av delägarna vara "den egentlige brukaren (huvudbrukaren)". ${ }^{26}$ Klart är emellertid att samägande inte var ovanligt i 1950-talets jordbruk. I och med rapporterna från Jordbrukets utredningsinstitut definierades företeelsen som ett socialt problem. Under det följande decenniet blev problemet politiskt.

\section{Sextiotal: ett hot mot rationaliseringen}

Förändringstakten i jordbruket var hög under 1950-talet, men ökade ändå avsevärt under 1960-talet. Decenniet såg en nedläggningsvåg utan tidigare motstycke; på tio år försvann mer än vart tredje svenskt jordbruk. ${ }^{227}$ Den yttre rationaliseringens mål - en ökning av brukningsenheternas storlek - började förverkligas. I början av 1950-talet var två tredjedelar av alla jordbruk mindre än 1o hektar, knappt två decennier senare utgjorde de mindre än hälften. ${ }^{228}$ Under denna strukturella omdaning framträdde samägandet som ett problem i flera avseenden. I början av 1960-talet påtalade den statliga Skatteflyktskommittén att det ökade dödsboägandet visserligen kunde bero på en strävan att behålla en släktgård i familjens ägo, men underströk att ägandeformen innebar skattetekniska fördelar för delägarna och efterlyste åtgärder. ${ }^{229}$ När jordförvärvslagen vid samma tid skulle omarbetas framställde den därtill utsedda utredningen ökningen av samägandet som ett problem eftersom jordägandet överfördes till andra än den jordbrukande befolkningen. Den hänvisade även till den pågående strukturomvandlingen: dödsboägande äventyrade rationaliseringstakten eftersom fastighetsrättsliga åtgärder krävde samtycke från samtliga delägare och därmed rent praktiskt var knepigt att erhålla. ${ }^{230}$

Trots kritiken innefattade förslaget till ny jordförvärvslag inga direkta åtgärder för att komma tillrätta med samägandeproblemen. Det första kravet på att gå från ord till handling framfördes istället i en skrivelse som Lantmäteristyrelsen, Lantbruksstyrelsen och Skogsstyrelsen gemensamt och på eget initiativ tillsände regeringen 1962. Den utlösande faktorn var farhågor för samägandets effekter på strukturomvandlingen. Inledningsvis gjorde de tre myndigheterna 
samma konstaterande som Jordbrukets utredningsinstitut: problemet gällde inte enbart dödsbon i "i teknisk-juridisk mening" utan även "den form av samlevnad mellan förutvarande dödsbodelägare, som innebär att ägarna efter boets delning [...] behåller ideella andelar i den dödes egendom" - det vill säga flerägda gårdar. ${ }^{231}$ Båda dessa samägandeformer ansågs bli vanligare, vilket knappast kunde förklaras med en ökning av antalet dödsfall utan snarare berodde på att arvingarna inte upplöste egendomsgemenskapen på samma sätt som tidigare. ${ }^{232}$ Vilka faktorer som låg bakom denna utveckling var inte entydigt - frågan ansågs "värd ett närmare studium" - men i skrivelsen listades en rad ekonomiska faktorer: ökande svårigheter att lösa ut arvingar, en "flykt till realvärden", svårigheter att bryta ut enskilda jordlotter, fördelaktiga beskattningsregler och svårigheter att erhålla kredit. ${ }^{233}$

I skrivelsen underströk de tre myndigheterna att samägda fastigheter stod i vägen för en effektiv rationaliseringspolitik och att problemet blivit allt mer påtagligt $\mathrm{i}$ takt med att rationaliseringsarbetet intensifierats. Två huvudproblem utkristalliserades: samägda gårdar deltog i mycket mindre grad i själva rationaliseringen och de utgjorde en flaskhals när det gällde förbättringsarbete på omkringliggande fastigheter. ${ }^{234}$ I förlängningen innebar en utveckling där dödsbon "mer eller mindre permanentas" att fastighetsmarknaden minskade, vilket försvårade nyetablering och utvidgning av befintliga enheter. ${ }^{235}$ Visserligen sades samägda fastigheter ännu 1962 utgöra en begränsad del av fastighetsbeståndet, men eftersom tendensen var ökande - här hänvisades bland annat till rapporterna från Jordbrukets utredningsinstitut - betecknades problemet som "mycket allvarligt". ${ }^{236}$ För att underlätta rationaliseringsarbetet föreslogs som en omedelbar åtgärd en lagstiftning om fastighetsombud: domstol skulle på initiativ av en delägare eller en myndighet kunna förordna ett ombud som skulle företräda fastighetsägarna som kollektiv i rättsliga förhandlingar och kontakter med myndigheter. ${ }^{237}$ Förslaget innebar visserligen inte någon lösning på "dödsboproblemet $\mathrm{i}$ stort" - det ansågs fordra grundlig utredning - men borde enligt de tre myndigheterna leda till en viss minskning av antalet egendomsförvaltande dödsbon. ${ }^{238}$ 


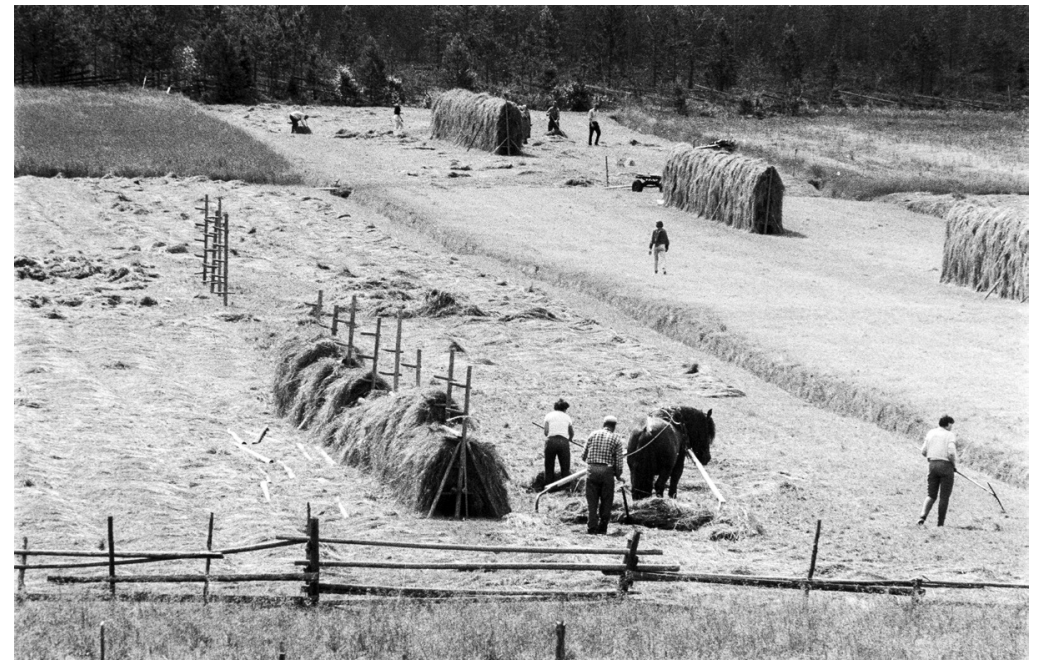

I samband med Sveriges lantbruksförbunds 50-årsjubileum 1967 fick fotografen Sune Jonsson i uppdrag att detta år fånga den pågående omvandlingen av jordbruket. Resultatet redovisades i en omfångsrik fotobok som utgör en fascinerande dokumentation av de moderna maskinernas intåg men också fångar det kvardröjande gamla. På bilden ovan från Jörn i Västerbotten tas höet om hand på hässjor och med häst som dragkraft. Jordbruket kunde ännu kräva en stor arbetsstyrka. Foto: Sune Jonsson/Västerbottens museum.

Regeringen tog frågan på allvar och sände förslaget på remiss, men det resulterade inte i någon ny lag. En anledning var sannolikt att förslaget fick relativt omfattande kritik från flertalet remissinstanser. ${ }^{239}$ Att lagstiftningsåtgärder inte kom till stånd bör dock också ses i ljuset av den omläggning som den statliga jordbrukspolitiken genomgick i mitten på 1960-talet. Antalet brukningsenheter hade på kort tid minskat dramatiskt och genom stora förvärv hade lantbruksnämnderna kunnat bygga upp en rejäl jordreserv för framtida rationalisering. Behovet av en restriktiv förvärvspolitik hade därmed minskat betydligt och den nya jordförvärvslag som antogs 1965 innebar på väsentliga punkter en uppmjukning av regelverket. ${ }^{240}$ Det fanns med andra ord inte tillräckligt starka skäl att ta krafttag mot samägandet. Frågan fick bero, men avgjord var den inte. Några år in på 1970-talet omstöptes jordbrukspolitiken på nytt och samägda jordbruksfastigheter hamnade åter i blickfånget. 


\section{Sjuttiotal: krav på begränsningar}

Efter 1960-talets mycket kraftiga minskning av antalet jordbruk fortsatte nedläggningarna in på 1970-talet, om än i något långsammare takt. Sett över hela decenniet försvann cirka 35000 brukningsenheter, vilket motsvarade drygt 23 procent. ${ }^{241}$ På många gårdar lades produktionen ned och ägandet överfördes så småningom till arvingar som inte längre bedrev jordbruk. Följden blev dock inte att ägandet samlades i större enheter utan att en allt större andel av jorden kom att brukas som arrende. Denna utveckling var särskilt påtaglig under 1960- och 1970-talen; 1975 brukades inte mindre än 40 procent av den totala åkerarealen på arrende. ${ }^{242} \mathrm{Vid}$ samma tid stod återigen en revidering av jordförvärvslagen på den politiska dagordningen och frågan om dödsbons jordägande fick ny aktualitet. Den utredning som arbetade fram det nya lagförslaget betonade sambandet mellan en ökad andel arrenderad jord och det likaledes ökade dödsboägandet. Till det vid det här laget väl inarbetade argumentet att samägda fastigheter försvårade rationaliseringsarbetet lades två nya: de samägda fastigheterna ansågs vara sämre skötta eftersom dödsbodelägarna ofta var bosatta på annan ort, och den ökande andelen arrenderad jord motverkade det jordbrukspolitiska målet att ägande och brukande skulle vara förenat. ${ }^{243} \mathrm{Nu}$ framfördes för första gången krav på lagstiftning för att begränsa samägandet. Visserligen innehöll inte utredningen något skarpt förslag i denna riktning - det var knappast möjligt inom ramen för utredningens uppdrag - men i betänkandet framhölls det som angeläget att begränsa möjligheten för dödsbon att "under längre tid inneha lantbruksföretag". 44

Det var inte enbart samägda fastigheter som stod i skottgluggen. En viktig förändring rörde jordförvärvslagens generella undantag vid förvärv mellan släktingar. Konsekvenserna av detta undantag var långtgående. Enligt Lantbruksstyrelsens statistik utgjorde släktförvärven två tredjedelar av samtliga förvärv. ${ }^{245}$ Prövning enligt förvärvslagstiftningen gjordes således bara för en mindre del av jordmarknaden. Utredningen gick till angrepp mot det vidsträckta släktundantaget. Redan 1942 års jordbrukskommitté hade pläderat för ett mer begränsat familjeundantag, med hänvisning till den planerade rationaliseringen, dock utan att vinna 
gehör. I förslaget till ny jordförvärvslag plockades idén upp igen. Utredningen gick rentav ett steg längre och argumenterade för att släktskapsundantaget principiellt borde avvecklas i sin helhet, men en så radikal åtgärd ansågs kunna leda till "icke önskvärda ingrepp från tillståndsmyndighetens sida i dispositioner inom den närmaste familjekretsen". ${ }^{246}$ Det konkreta förslaget stannade vid att undantag framöver enbart skulle lämnas för "närmast arvsberättigade, dvs. make och avkomling", vilket innebar att framför allt syskon och syskonbarn inte längre skulle vara undantagna kravet på förvärvsprövning. ${ }^{247}$ Åtgärden var knappast försumbar; försäljningar till syskon och syskonbarn hade tidigare motsvarat ungefär en femtedel av samtliga släktförvärv. ${ }^{248}$ Riksdagen gick på utredningens linje, även om debattens vågor stundtals gick höga. ${ }^{249}$

Med antagandet av 1979 års jordförvärvslag beskars således släktskapsundantaget och syskons transaktioner med arvslotter hamnade under förvärvsprövning. Till viss del underkändes därmed principen om att arvsfrågan skulle lösas inom familjen. Så länge syskonen fortsatte att ärva och behålla sina arvslotter hände emellertid inget, eftersom de nya bestämmelserna inte innehöll några åtgärder mot samägda jordbruksfastigheter. Men bollen hade satts i rullning. I slutet av 1970-talet tillsattes en särskild utredning med fokus på samägandeproblematiken. Uppdraget gällde dels former för förvaltning av dödsbon och samägda jordbruksfastigheter, dels åtgärder för att begränsa samägandet. ${ }^{250}$

\section{Åttiotal: problemets lösning?}

Utredningen om samägda fastigheter avlämnade under 1980-talet två betänkanden: ett förslag om ställföreträdare för vissa samägda jordbruksfastigheter (SOU 1981:93) samt ett förslag om begränsning av dödsboägande och samägande av jordbruksfastigheter (SOU 1987:2). I båda förslagen sades samägande av jordbruksfastigheten leda till en rad bekymmer, varpå föregående decenniers problembild rekapitulerades. Det viktigaste problemet var av praktisk art och berodde främst på egendomens förvaltningsregler. Svårigheter att komma i kontakt med alla delägare sades vara ett stort problem 
för myndigheter. Kravet på enighet mellan delägarna i frågor om egendomens skötsel riskerade dessutom att leda till en ineffektiv eller rentav skadlig förvaltning. Var delägarna oeniga inträdde ett slags handlingsförlamning. Samägande framställdes också som problematiskt ur ett politiskt perspektiv, särskilt ifråga om jordbruks-, regional- och sysselsättningspolitik. Ambitionsnivån på rationaliseringsarbetet sänktes (på sina håll sades arbetet rentav ha upphört), det jordbrukspolitiska målet om nära samband mellan ägande och brukande motverkades när delägarna inte längre deltog i jordbruket och den stela fastighetsstrukturen minskade omsättningen på jordbruksfastigheter. Ett mindre utbud av jord på marknaden hindrade i sin tur nyetableringar och utvidgningar av befintliga jordbruk och var därmed till men för landsbygden $\mathrm{i}$ stort. ${ }^{251}$

Trots att jordbruksstatistiken hade förfinats väsentligt under 1960- och 1970-talen kunde utredningarna inte presentera säkra siffror på samägandets omfattning. Dödsbon särredovisades i viss mån som företag från och med 1971 års jordbruksräkning, däremot saknades i allt väsentligt uppgifter om samägda fastigheter. ${ }^{252}$ Inom ramen för utredningen genomfördes därför en bearbetning av 1979 års allmänna fastighetstaxering för att kartlägga ägandeförhållanden. Det visade sig att ungefär tio procent av jordbruksfastigheterna ägdes av dödsbon och ungefär sju procent var flerägda (av mer än två delägare). Knappt femton procent ägdes av två delägare, men merparten av dem bedömdes vara makar eller sambor. ${ }^{253}$ Ägandeförhållanden inom äktenskapet ansågs ligga utanför utredningens mål och fokus riktades mot dödsbon och flerägda fastigheter, vilka sammantaget utgjorde ungefär en sjättedel av Sveriges jordbruksfastigheter 1979 .

De regionala skillnaderna var stora, om än något svårtydda. Ett tydligt drag var dock att skogslän utmärkte sig med en större andel fastigheter ägda av dödsbon. ${ }^{254}$ Kopparbergs län hade en ohotad topplats med över tjugo procent dödsbon, följt av Jämtlands, Värmlands och Norrbottens län. I slättbygderna var dödsboägande ovanligare. De två Skånelänen intog jumboplatserna, båda med en dödsboandel på klart under fem procent. Flerägda fastigheter 


\section{DÖDSBOFGANDE och samägande av jordbruksfastighet m.m.}

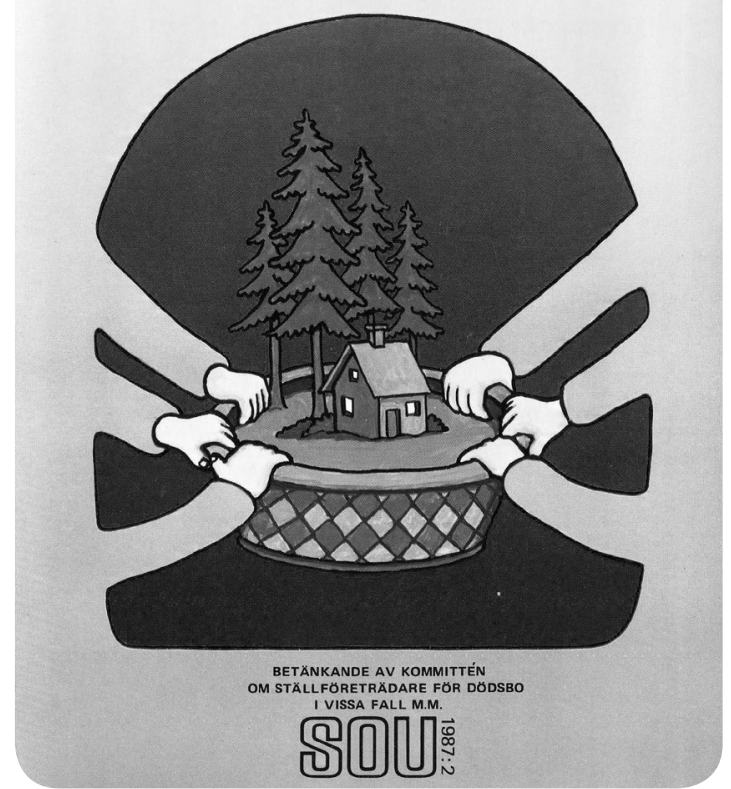

Illustrationen till betänkandet om dödsboägande anspelar på svårigheterna att hantera något med många händer inblandade. Att lantbrukets karaktäristiska ekonomibyggnader saknas på bild ger i kombination med de högresta granarna en tydlig indikation på att skogens ökande värde var en orsak bakom allt fler samägda fastigheter.

uppvisade inte något lika tydligt mönster. De var vanliga i skogslän som Värmland, Jämtland och Kopparbergs län, men också i slättbygdsbetonade län som Östergötland. ${ }^{255}$ Ett distinkt drag var att större fastigheter, särskilt från 50 hektar och uppåt, oftare var flerägda. ${ }^{256}$

Att samägda fastigheter var vanligare i skogsrika trakter indikerar att en viktig orsak bakom ägandeförhållandena var att värdefull egendom tycks ha behållits av arvingar som inte längre bodde kvar på 
fastigheten. Samägandet var dock på intet sätt begränsat till skogslänen och det är svårt att skönja något övergripande geografiskt mönster. ${ }^{257}$ Mot denna bakgrund är det överraskande att utredningarna saknar all tillstymmelse till analys om samägandets drivkrafter. Att det fanns gott om samägda fastigheter är uppenbart, att de ansågs utgöra ett problem likaså, men varför de hade uppstått och blivit så utbredda berörs inte i något av utredningens betänkanden.

Utredningen föreslog två åtgärder: för att underlätta myndigheters arbete skulle en ställföreträdare utses för samägda jordbruksfastigheter med tre eller fler delägare, och dödsbon som ägde jordbruksfastigheter skulle åläggas att avveckla fastighetsinnehavet genom skifte eller försäljning inom fem år från dödsfallet. Riksdagen gick i allt väsentligt på utredningens förslag. I och med lagen om förvaltning av vissa samägda jordbruksfastigheter och ändringar $\mathrm{i}$ ärvdabalken sattes 1989 punkt för en flera decennier lång debatt om samägandets problematik.

Regeln om tidsbegränsad avveckling gällde enbart dödsbon, inte flerägda fastigheter. En motsvarande regel för denna kategori diskuterades i ett av betänkandena men föreslogs aldrig. Skälen var dels att det vore svårt att avgöra vilka typer av samäganden som borde avvecklas, dels att en sådan regel skulle inkräkta på såväl arvs- som äganderätten. En ägare borde, resonerade utredningen, vara fri att överlåta sin egendom till sina barn på ett rättvist sätt, och ett direkt förbud mot samägande riskerade leda till att föräldrar istället sålde arvegodset. Samtidigt underströks det eftersträvansvärda i att fastigheter inte splittrades. ${ }^{258}$ Den grundläggande tanken att inlösenförfarandet skulle lösas av och inom familjen var alltjämt stark.

\section{Det svårfångade samägandet}

Med förändringarna i egendomsrätten under 1800-talets lopp ändrades förutsättningarna för hur generationsskiften skulle genomföras. Reglerna för inlösen mellan arvingar avvecklades och hur arvet slutligt skulle delas upp blev i större utsträckning en fråga för familjerna, framför allt arvingarna själva. Tilltron till att frågan vanligen 
löstes så att en arvinge övertog hela fastigheten var uppenbart stor: Lagberedningen avstod 1933 att införa inlösensbestämmelser eftersom erfarenheten visat att saken löstes inom familjerna. Med tiden förklingade emellertid de positiva erfarenheterna och samägande utkristalliserade sig som ett jordpolitiskt problem.

För en nutida läsare är det slående hur svårt den samtida jordbruksstatistiken hade att finna rimliga ägarkategorier för att analysera utvecklingen. Den totalt dominerande kategorin, enskilt ägande, bröts länge inte ned i underkategorier. Så småningom började dödsbon särredovisas, men den praktiska skillnaden kunde vara minimal mellan å ena sidan ett oskiftat dödsbo och å andra sidan ett skiftat bo där varje arvinge erhållit sin ideella andel i egendomen. Både dödsbon och flerägda fastigheter var samägda och omfattades av likartade förvaltningsregler, där enighet mellan delägarna var en förutsättning för ett effektivt bruk av fastigheten. Likheten mellan dessa ägandeformer illustreras väl $\mathrm{i}$ juristen Margareta Brattströms utvärdering av effekterna av 1989 års lag om avveckling av dödsbos fastighetsinnehav. Hon konstaterar att lagen visserligen följts, men att den många gånger inneburit att dödsbon avvecklats så att delägarna istället erhållit sina andelar i fastigheten. Dödsboägda fastigheter har blivit flerägda. Själva samägandet tycks med andra ord inte alltid ha upphört. ${ }^{259}$

Samägande av jordbruksfastigheter är en viktig del av 1900-talets agrara historia, men jordbruksstatistiken gör det svårt att dra säkra slutsatser om hur utbrett det var, särskilt under seklets första hälft. Enstaka uppgifter i utredningar indikerar att det förekom, men inte omfattningen. Först för 1950-talet börjar det bli möjligt att få mer säkra uppgifter och då var en god bit över 10 procent av landets jordbruksfastigheter samägda, en andel som ökade till 17 procent runt 1980. Förhoppningen att inlösensfrågan skulle lösas inom familjerna infriades med andra ord långtifrån alltid. Det fanns ett stort antal generationsskiften som kom av sig.

Att inlösen mellan arvingar långtifrån alltid fullföljdes kan ses som en icke-händelse, det vill säga en förväntad men utebliven händelse. Vad döljer sig då bakom alla samägda fastigheter? Drivkrafterna och bakgrunden till det gemensamma ägandet har sällan 
kartlagts, men klart är att kategorin innehåller flera olika varianter och att fördelningen dem emellan sannolikt har förändrats över tid. I många fall berodde ägandestrukturen på ett nyligen timat dödsfall, och samägandet upphörde genom en inlösensprocess inom något år. Då var dödsboägande en temporär ägandeform som ett led i en högst ordinär generationsväxling. Mycket tyder dock på att samägandet i många fall bestod under en lång följd av år som en permanent ägandeform. Till de fallen hör ett stort antal nedlagda brukningsenheter där jorden arrenderades ut. Denna företeelse blev troligen vanligare under 1960- och 1970-talen i takt med den snabba jordbruksomvandlingen och i takt med en stark urbanisering. En fastighet kunde behållas i gemensam ägo av känslomässiga skäl, men även av ekonomiska. Att dödsboägandet runt 1980, när analysen kan brytas ner på länsnivå, var särskilt markerad i skogslän indikerar värdet av att behålla skogen som ett framtida kapital, som det dessutom var möjligt att sköta på distans. När samägandet började uppmärksammas vid seklets mitt var det dock en annan ägandesituation som stack ut: samägande mellan syskon som bodde tillsammans på fastigheten. Som rapporterna från Jordbrukets utredningsinstitut visar var det i huvudsak syskon som återfanns på de samägda fastigheterna, ofta ogifta och ibland tillsammans med en förälder. Syskonjordbruket tycks med andra ord vara en realitet, åtminstone vid seklets mitt.

Bakgrunden till samägandet kan kopplas samman med familjens funktion och betydelse. Här framträder en utveckling över tid. I den jordpolitiska debatten manifesterades olika familjeideal och ett mer utvidgat familjebegrepp ifråga om jordägande gjorde sig gällande långt fram i tiden. Medan familjen länge utgjorde jordpolitikens minsta beståndsdel - som på egen hand förutsattes fullfölja generationsväxlingar och på alla sätt skulle skyddas mot utostående hot, särskilt från marknaden - framträdde från 1950-talet en skarpare motsättning inom familjen som ställde familjemedlemmar mot varandra. Efter jordförvärvslagens förändring på 1970-talet utmönstrades slutligen syskon från släktundantaget och kvar fanns endast kärnfamiljen. Motsättningarna innebar att den utvidgade familjen som kollektiv aktör löstes upp och ersattes med individer, 
som kunde ha sinsemellan rakt motsatta strategier. Ur ett sådant perspektiv framstår syskonjordbruken som något av en gåta. Uppstod de till följd av flera arvingars strategiska val eller som ett slags kompromiss - ett givande och tagande mellan motstridiga strategier? Vilken roll kön spelade i utvecklingen är också svårt att säga. Det är påfallande att lagstiftningen om samägande och över huvud taget de första indikationerna på att arvingar kunde behålla sina arvslotter under avsevärd tid kom samtidigt som söners rätt att lösa ut döttrar utmönstrades ur lagstiftningen. I vilken utsträckning har syskonjordbruk varit en kvinnlig strategi för att behålla sin ärvda egendom?

\section{Två avslutande frågor}

De institutionella ramarna omvandlades från slutet av 1800-talet fram till 1900-talets slut, från 1890 års slopande av bröders lösningsrätt till 1989 års försök att stävja dödsbons jordägande. De nya förutsättningarna möjliggjorde nya handlingsmönster och strategier. Istället för att gården med laglig rätt inlöstes av en arvinge började andra alternativ utkristallisera sig. Det viktigaste var att samägande mellan arvingar underlättades. Det är svårt att ge någon enkel och omedelbar förklaring till samägandet, och mycket talar för att det bakom begreppet fanns flera olika företeelser vilkas betydelse varierade över tid. Det är dock påfallande att förekomsten av samägda fastigheter främst uppmärksammades och uppfattades som ett problem i relation till efterkrigstidens strukturrationalisering. Till viss del kanske det ökade samägandet kan sägas ha varit en effekt av rationaliseringen. När jordbruk började slås ut fanns fortsatt ett starkt äganderättsligt skydd. De nedlagda enheterna kunde bara användas för rationalisering med ägarnas medgivande, och så länge egendomen stannade inom släkten begränsade släktundantaget den statliga inblandningen. Det är inte heller orimligt att incitamenten för att fullfölja inlösensprocessen kan ha minskat om jordbruksdriften lades ner.

Att samägandet identifierades som ett samhälleligt problem under efterkrigstiden kan ha berott på att det var först då som det 
på allvar blev vanligt, men också på att det var först under den nya jordbrukspolitiken som det uppmärksammades. En viktig fråga är således om samägandet utvecklades till en viktig ägandeform redan under 1900-talets första hälft.

En andra fråga gäller samägandets geografi. Att det mot seklets slut var vanligare med gemensamt ägande i skogslänen kan ses som en indikation på skogens ökande värde, men fanns liknande mönster även tidigare? Det saknas användbar statistik av ägandeförhållandena före seklets mitt, så svaret måste sökas med andra metoder. Det görs i nästa kapitel. 